\title{
Teología feminista judía: diversas maneras de nombrar a la divinidad en la liturgia judía
}

\section{Rabina Daniela Szuster}

Rabina ordenada en el Seminario Rabínico Latinoamericano Marshal T. Meyer z"1 de Buenos Aires, Licenciada en Psicología de la Universidad de Buenos Aires, Master en Ciencias Judaicas del Schechter Intitute of Jewish Studies en Jerusalén, egresada de la Maestría en Estudios de la Mujer dictada conjuntamente en la Universidad de Costa Rica (UCR) y en la Universidad Nacional (UNA) y Rabina de la Congregación B'nei Israel de San José, Costa Rica desde el año 2004.

Correo electrónico: danielaszuster@yahoo.com.ar

Recibido: 15 de abril 2013 • Aprobado: 27 de junio 2013

\begin{abstract}
RESUMEN
El propósito de este artículo es, en primer lugar, plantear los problemas teológicos que implica reconocer a Dios con pronombres, sustantivos y cualidades de índole masculino en nuestros días. En segundo lugar, mostrar la importancia de explorar diferentes maneras de nombrar y acercarse a la divinidad dentro de la tradición judía. Por último, desarrollar tres propuestas diferentes planteadas por distintitas pensadoras feministas judías, para incluir en la liturgia judía, intentando armonizar los problemas teológicos presentados.
\end{abstract}

Palabras claves: Teología - feminismo- judaísmo-liturgia-divinidad.

\section{ABSTRACT}

The purpose of this article is, first, to present the modern-day theological problems posed by referring to God using masculine nouns, pronouns and qualities. Second, the article advocates the importance of exploring the different ways Jewish tradition has for naming and approaching the Divinity. Finally, the perspectives of three Jewish feminists are presented, to include in the Jewish liturgy, as a means of resolving the theological conflicts identified.

Key words: Theology-feminism-juadism-liturgy-divinity.

\section{Introducción}

¿Cómo se imaginaba a Dios en la infancia? Al preguntar este interrogante a diferentes personas, muchos suelen responder diciendo como un hombre con barba blanca, un superhéroe, un rey, un mago, un papá, etc. Si comparamos las diferentes maneras de ver a Dios, podemos encontrar un eje en común: están ligadas a imágenes masculinas de la sociedad. Difícilmente responderán que la ven como una reina, una madre, una heroína, un hada, etc. ¿A qué se debe este fenómeno?

Sin duda, la manera que tenemos de concebir a la divinidad está muy ligada a la educación religiosa que recibimos en nuestra vida. La gran mayoría de las religiones occidentales presentan en sus orígenes cosmovisiones arraigadas a valores y culturas patriarcales, en las que se dan relaciones desiguales de poder entre hombres y mujeres, teniendo el hombre un lugar de prestigio y la mujer, 
un lugar de subordinación. Luisa Posada Kubissa define al patriarcado de la siguiente manera:

“...como ese entramado de pactos que pone el control de la sociedad en manos masculinas. De este modo, el poder recae en los hombres, poder que, en nuestras actuales sociedades desarrolladas, pasa por los núcleos relacionados con la política y la economía. Y, con ello, las mujeres quedan excluidas de todo el ámbito de las decisiones que afectan a las sociedades en las que viven" (Posada, 1995:331).

Si en estas sociedades, el hombre es quien detenta el poder, privilegios, capital y presenta un status superior que la mujer, es lógico que se antropormofice a la divinidad, autoridad superior y absoluta, con los hombres más que con las mujeres. Sin duda, la manera en que se concibe a la divinidad refleja la forma en que se organiza y vive la sociedad.

La tradición judía no está exenta de este fenómeno. Muchos de los nombres que tradicionalmente se usan para nombrar a la divinidad, son pronombres, sustantivos o adjetivos de género masculino. Este inconveniente ha sido identificado por diferentes pensadoras judías, principalmente, aquellas que iniciaron con los estudios acerca de la teología feminista judía.

Haciendo una breve sinopsis, la teología feminista judía surge en los años setenta, en el marco de los estudios de género y judaísmo. Uno de los temas centrales desarrollado es acerca de los lenguajes utilizados para nombrar a Dios y el cuestionamiento sobre la construcción de un Dios masculino en la tradición judía. El primer artículo que surge sobre el tema es el de Rita Gross en el año 1979 llamado "Female God Language in a Jewish Context", el que dio pie a otros desarrollos sobre el tema.

La publicación del Siddur Nashim en 1976 por Naomi Janowitz y Margaret Wenig fue un hito que revolucionó la teología feminista judía, al tener la experiencia de rezar a Dios utilizando pronombres e imágenes femeninas.

El libro de Judith Plaskow, "Standing Again at Sinai: Judaism from a Feminist Perspective" (1991), es el primer libro que se ha escrito sobre teología feminista judía. Sus capítulos atraviesan diferentes conceptos como ser la Torá, la halajá (ley judía), Israel, Dios, sexualidad y reparación del mundo.

El siguiente libro que también ha sido íntegramente enfocado a este aspecto es el de Rachel Adler "Engendering Judaism: An Inclusive Theology and Ethics" (1999).

Sin duda, la teología feminista judía, es un área que nació hace poco tiempo comparando la historia de la tradición judía y se está desarrollando vertiginosamente.

Varias de estas autoras han dado propuestas concretas de cómo resolver el problema teológico presentado con anterioridad.

La idea de este artículo es, en primer lugar, plantear los problemas teológicos que implica reconocer a Dios con pronombres, sustantivos y cualidades de índole masculino en nuestros días. En segundo lugar, mostrar la importancia de explorar diferentes maneras de nombrar y acercarse a la divinidad dentro de la tradición judía. Por último, desarrollar tres propuestas diferentes a implementar en la liturgia judía, planteadas por distintitas pensadoras feministas judías, intentando armonizar los problemas teológicos presentados.

\section{Problema teológico contemporáneo}

Es un hecho que la liturgia judía tradicional se dirige a Dios utilizando metáforas y adjetivos masculinos. Ahora, ¿cuál podrá ser el problema teológico de continuar en nuestros días con estas imágenes masculinas acerca de la divinidad?

En primer lugar, es una manera de continuar reproduciendo esta desigualdad de poder y justificar que el hombre es a quien le corresponde un lugar superior y a la mujer, un lugar subordinado. Judith Plaskow, feminista judía, hace el siguiente planteo:

If God is male, and we are in God's image, how can maleness not be the norm of Jewish humanity? If maleness is normative, how can women not be Other? And if women are Other, how can we 
not speak of God in language drawn from the male norm? (Plaskow, 1987:228). ${ }^{1}$

Para decirlo de una manera más clara, concebir a Dios como masculino implica que la mujer quede marginada a un status inferior, no pudiendo ser parte del famoso versículo de Géneisis: " $Y$ creó Dios al hombre a su imagen, a imagen de Dios los creó, varón y hembra los creó" (Génesis 1:27). Entonces, de alguna manera, el dirigirnos a Dios con metáforas masculinas, contradice esta fuente bíblica, descartando la idea de que la mujer fue y es creada a imagen de Dios.

En segundo lugar, este interrogante se une a una antigua controversia acerca de la manera de dirigirnos a Dios. Si la incorporeidad de Dios es un principio de la tradición judía, ¿cómo es que la Torá (pentateuco) nos habla muchas veces de Dios con cualidades físicas humanas? Es un interrogante que ha trascendido durante siglos. Algunos pensadores judíos han respondido argumentando que existe una necesidad humana de antropormofizar a Dios, adjudicándole cualidades humanas tanto físicas como psicológicas, dado que nos es muy difícil de acceder al concepto divino de una manera completamente abstracta. Es una especie de concesión que hacen algunos sabios, con el fin de que las personas puedan tener un contacto más profundo, pero sin creer que Dios es una persona de carne y hueso, son sólo metáforas acerca de Dios.

Iehuda Halevi es uno de los filósofos de la Edad Media que acordaba con esta postura. En cambio, Maimónides, racionalista por excelencia, fue uno de los grandes opositores de la idea de permitir antropomorfizar a Dios al punto de declarar en "La guía de los perplejos" que todo antropormofismo es una rotunda herejía. (Encyclopedia Judaica, 1971: vol.3 , p. 56).

1. "Si D"s es masculino, y somos a imagen de Dios, ¿cómo puede la masculinidad no ser la norma de la humanidad judía? Si la masculinidad es normativa, ¿cómo pueden las mujeres no ser lo Otro? Y si las mujeres son lo Otro, ¿cómo podemos no hablar de Dios en lenguaje extraído de la norma masculina?" (Plaskow, 1987:228).
Entonces, ya en la Edad media se discutía y se cuestionaba acerca de las consecuencias de ver a Dios con cualidades típicamente humanas. Hoy en día, uno de los aspectos de este debate de antropomorfizar a Dios, es el hecho de ver a Dios desde un solo género, sin la posibilidad de verlo de otra manera.

Esto no quiere decir, como muchos suponen, que las feministas sostengan que Dios es femenina, sino, como lo plantea la pensadora Rita Gross, el problema no tiene que ver con la esencia de Dios sino en las metáforas e imágenes que le atribuimos los humanos:

"Let me say immediately that I am quite aware that God is not really either female or male or anything in between. I only wish the people who argue to retain solely male imagery were as aware that God is not really male as I am that is not really female. I am talking about the only thing we can talk about_ images of God, not God" (Gross, 1979:168).

Como dice Gross, se trata de imágenes, metáforas, que nos ayudan a entender y expresar lo que sentimos y percibimos acerca de la divinidad. Si acordamos que se está discutiendo acerca de imágenes de Dios y no de Dios mismo, por qué limitarnos a determinadas metáforas y no a otras. El percibir a la divinidad solamente de manera masculina nos limita y restringe nuestra manera de concebirlo.

En tercer lugar, es significativo resaltar la importancia que presentan las metáforas e imágenes que se construyen acerca de la divinidad, transmitiendo éstas un poder y una fuerza mucho más grande que cientos de ensayos y tratados. De esta manera, lo describen Neil Gillman y Elliot Dorff respectivamente:

2. "Permítame decir inmediatamente que estoy muy consciente de que Dios no es realmente femenino ni masculino, ni nada entre medio. Solamente deseo que las personas que discuten tan sólo para conservar la imaginería masculina, sean conscientes de que Dios no es realmente masculino, al igual que estoy de acuerdo de que no es femenino. Estoy hablando de lo único que podemos hablar: imágenes de Dios, no de Dios". (Gross, 1979:168). 
“...metaphors serve to capture, in a Sharp and vivid way, an elusive and complex piece of information that escapes clear and concise expression" (Gillman, 2000: s.p.). ${ }^{3}$

\begin{abstract}
"Images convey values through pictures much more effectively than general statements can"..." Because images are concrete; they have more power than abstract principles do to impress these lessons upon us". (Dorff, 1993: 224 y 228)
\end{abstract}

Las metáforas son simplemente un medio para entender los misterios y complejos caminos de la divinidad. Y si determinadas metáforas se leen y se repiten diariamente en la liturgia, indefectiblemente van a moldear una determinada visión acerca de Dios. Como lo asevera Judith Plaskow:

"The liturgy has come to have a formative role in shaping the Jewish picture of deity. Since metaphors of God's power as dominance are central to the liturgy, these metaphors have profoundly affected the Jewish imagination, building and solidifying a particular understanding of God" (Plaskow, 1990: 129).

Por esto, es de suma importancia tener un cuidado especial, analizar y reflexionar sobre la manera que solemos dirigirnos a la divinidad y darnos la posibilidad de abrir el abanico y verlo o verla de otras maneras.

3. “...las metáforas sirven para capturar, de forma nítida y vibrante, un trozo de información difícil de alcanzar y complejo, que escapa a la expresión clara y concisa" (Gillman, 2000: sp).

4. "Las imágenes transmiten valores mediante fotos más eficazmente de lo que lo pueden hacer los enunciados generales" [...] "Dado que las imágenes son concretas, tienen más poder que los principios abstractos para imprimir estas lecciones sobre nosotros". (Dorff, 1993: 224 y 228).

5. "La liturgia ha llegado a tener una función formativa en la configuración de la imagen judía de la deidad. Ya que las metáforas del poder de Dios como dominante son fundamentales para la liturgia, estas metáforas han afectado profundamente a la imaginación judía, construyendo y solidificando una comprensión particular de Dios". (Plaskow, 1990: 129).

\section{Diversas maneras de nombrar a la divinidad en la tradición judía}

En la tradición judía encontramos diferentes maneras de concebir a Dios, diferentes nombres, que se pueden apreciar en diferentes fuentes. Por ejemplo, en el libro de Éxodo, Dios mismo se hace llamar de diferentes maneras con distintas personas:

"Habló Elohim a Moshé y le dijo a él: Yo soy Adonai. Yo me aparecí a Abraham, a Itzjak y a Iaakov por El-Shaddai, empero por Mi nombra Adonai no Me he dado a conocer a ellos" (Éxodo 6:2-3).

En este pasaje, Dios afirma haberse aparecido a los patriarcas de una manera particular, como El Shadai (Dios todopoderoso), mientras que a Moshé se le reveló con el nombre de Adonai (YHVH, tetragrama, nombre inefable). ¿Qué significa que Dios se le apareció de manera diferente a los patriarcas que a Moshé? ¿Por qué escogió $E l$ Shadai para acercarse a los patriarcas y Adonai a Moshé?, ¿Qué particularidades presentan cada uno de estos nombres?, ¿Un nombre es más importante que otro? En fin, estas palabras encierran una gran gama de misterios en relación a los nombres de la divinidad.

Rambán (Najmánides, exégeta, místico y filósofo del S. XIII) explica estos interrogantes argumentando que estos dos nombres se refieren a maneras diferentes en que Dios se revela a los seres humanos (Ver exégesis de Najmánides sobre Éxodo 6:2-3). En este sentido, El Shadai expresa la revelación divina que se manifiesta en las mismas leyes de la naturaleza, sin trastocar su funcionamiento habitual. Dios se reveló a los patriarcas, sin embargo, el mundo siguió funcionando normalmente. En cambio, el nombe Adonai expresa la revelación divina que se manifiesta mediante señales y milagros provocando que las leyes de la naturaleza, en el momento del milagro, se corrompan. Entonces, El Shadai y Adonai, son dos maneras diferentes en que la divinidad se presenta a los seres humanos.

Iehuda Halevi (filósofo del S. XI) enfatiza que esta distinción de nombres se refiere a 
necesidades espirituales diferentes. Los patriarcas no necesitaron de pruebas y milagros para ser fieles a D"s, en cambio, el pueblo, ya más numeroso y dubitativo, necesitó de grandes milagros para creer en el creador (Halevi, 1140:2).

No sólo se puede apreciar una diferencia en la manera de revelarse D"s a los patriarcas que a Moshé, sino, incluso podemos encontrar diferencias entre los mismos patriarcas. Un ejemplo lo podemos observar en la primera bendición de la oración de la Amidá (oración silenciosa principal de los tres rezos diarios): "Bendito eres Tú Adonai, Dios nuestros y de nuestros patriarcas; Dios de Abraham, Dios de Isaac y Dios de Jacob”.

Uno podría preguntarse por qué dice "Dios de Abraham, Dios de Isaac y Dios de Jacob", ¿acaso no es el mismo Dios? A lo que varios sabios responden: con cada uno de los patriarcas Dios tuvo una relación muy diferente, dependiendo de la situación y la manera de ser de cada uno de ellos.

Existen muchísimas otras fuentes en la tradición judía que reflejan esta idea, de las diferentes maneras en que Dios se revela y en que los seres humanos se acercan y conciben a la divinidad. Por ejemplo:

- "Dios es como un ícono que nunca cambia, sin embargo, todo el que mira, ve un rostro diferente" (Midrash Pesikta deRav Kahana, 110a).

- "Te concibieron en múltiples visiones, mas eres único en todas tus manifestaciones" (Rezo Shir Hakavod, en Majzor, Seminario Rabínico Latinoamericano, 1986: 40). D"s es uno pero cada uno lo percibe manera diferente.

- “La voz de D"s en la fuerza", en la fuerza de cada uno. Los jóvenes según sus capacidades, los ancianos según sus capacidades, los niños según sus capacidades. Dijo El Santo Bendito Sea al pueblo de Israel, no porque escucharon muchas voces van a pensar que existen varios dioses hay en el cielo sino sabrán que yo soy Adonai vuestro D"s: "Yo soy el Eterno, tu D"s" (Deuteronomio 5:6). (Shmot Rabá Parashá 29).
Siguiendo esta fuente, incluso una misma persona en sus diferentes etapas de la vida, puede percibir a la divinidad de manera muy diferente.

Todas estas fuentes, de alguna manera, expresan que Dios no se acerca del mismo modo a cada persona y a la vez, que es positivo y enriquecedor que cada uno pueda acercarse a él de maneras diversas, desde la forma particular de ser de cada uno. Siguiendo esta idea, el pensador Neil Gillman afirma que son numerosas las imágenes que tenemos de Dios porque están formadas por incontables seres humanos (Gillman, 2000).

Estas fuentes, evidencian que está bien visto dentro de la tradición judía el hecho de explorar diversas maneras de ver y acercarse a la divinidad.

\section{Propuestas judías feministas de cambios en la imagen de la divinidad en la liturgia judía}

La liturgia judía se puede encontrar principalmente en un libro denominado "Sidur", que significa "orden" en español. El Sidur nos ordena y organiza los rezos diarios (tres veces al día), semanales y los de las diferentes festividades y celebraciones. Los rezos tienen un orden y una estructura, la cual seguimos en comunidad. Algunos rezos provienes de libros de la Biblia Hebrea como ser de "Los Salmos", "Profetas", versículos de diferentes partes del "Pentateuco" y otros, provienes del Talmud e, incluso, de épocas posteriores, como poemas escritos en la Edad media y reflexiones de la época contemporánea.

El rezo es principalmente colectivo; para gran parte de los rezos, se requiere un Minián, un mínimo de diez personas judías, para poder llevarlas a cabo, y un Sheliaj Tzibur, una persona conocedora de la liturgia quien los conduce. El Sidur es una guía cuyo máximo objetivo es inspirar y ayudar al feligrés a conectarse con Dios de una manera profunda y significativa diariamente.

$\mathrm{Si}$ nos adentramos en la liturgia judía podemos encontrar que gran parte de la forma de concebir a Dios es con pronombres, cualidades y lugares de la sociedad masculinos, como ser:

- "Bendito eres Tú Adonai, Dios nuestro, Rey del universo..." De esta manera comienza la 
fórmula tradicional de las bendiciones ( $\mathrm{Si}$ dur, Seminario Rabínico Latinoamericano, 1999:1).

- "Creador del mundo, Rey Supremo..." (Plegaria Adón Olam), (Ídem., pag. 2).

- "Padre celestial, otórganos tu misericordia por amor a tu magno nombre que es invocado por nosotros" (Plegaria Birkot Hashajar), (Ídem., pag. 7).

- "Exaltado, venerado y alabado sea el nombre del Santo Bendito Él” (Plegaria Kadish), (Ídem., pag. 9).

- "Dios, triunfa en las batallas, Adonai es su nombre..." (Shirat Haiam, extraído de Shemot 15), (Ídem., pag. 29).

- "Santo, santo, santo es el señor de las huestes, toda la tierra está llena de su gloria" (Plegaria Kedushá), (Ídem., pag. 38).

- "Padre nuestro, perdona nuestros errores, absuélvenos de nuestras transgresiones..." (Plegaria Amidá), (Ídem., pag. 39).

- "Padre nuestro, rey nuestro hemos errado ante Ti... "(Plegaria Avinu Malkeinu), (Ídem., pag. 46)

Como se puede apreciar en estos ejemplos, diariamente, el devoto judío repite estos pronombres y cualidades acerca de Dios. Construye una imagen de Dios basada en roles característicos de los varones en la sociedad occidental; se lo ve como un Rey, un padre, Jefe de los ejércitos. Además de dirigirse a él con pronombres masculinos.

Varias autoras feministas judías analizaron este fenómeno de la liturgia judía tradicional y propusieron diferentes caminos para resolver esta situación de desigualdad que se vive, cada vez que rezamos utilizando este lenguaje. A continuación presentaré tres propuestas diferentes:

\section{Dirigirse a dios utilizando el género masculino y femenino:}

Esta primera propuesta consiste en hacer cambios en la liturgia, incluyendo nombres de Dios tanto en forma masculina como femenina. No porque se crea que Dios presenta ambos géneros sino para no encasillarse en un solo, mostrando a los feligreses una visión más amplia y diversa acerca de la divinidad, en la que se vea representados ambos géneros humanos; lo que puede contribuir a la construcción de una sociedad más equitativa, igualitaria y digna en relación a la diferencia de género.

Cabe aclarar que el rezo judío se desarrolla en hebreo, entonces algunos ejemplos los citaré en hebreo, además con su transliteración y traducción en español correspondiente.

Así es como, por ejemplo, se proponen los siguientes cambios:

- Rita Gross propone que, en lugar de que aparezca solamente הקדוש ברוך הוא", (Hakadosh Baruj Hu), "El Santo Bendito sea”, aparezca también הקדושה ברוכה היא "Ea , (Hakdoshá Brujá Hí), "La Santa Bendita sea" (Gross, 1979:173).

- En el Siddur Nashim (Libro de rezos de mujeres) de Janowitz y Wenig se presenta: "Magnificado y santificado en el gran Nombre de D"s a través del mundo que Ella creó conforme a Su voluntad. Pueda Ella establecer Su dominio en los días de tu vida..." (Janowitz y Wenig, 1976).

- En el Sidur (libro de rezos) de la comunidad Kol Haneshamá de Jerusalén se cambia la forma clásica de hacer las bendiciones, en lugar de decir:

"Bendito eres Tú, Rey del Universo...", aparece:

"ברוכה את יה השכינה חי העולמים" 
"Bendita eres Tú (en la forma hebrea femenina de "Tü") Iá, la Shejiná, (nombre alusivo tradicional a la presencia divina en forma femenina), únicamente Tú concedes la vida al universo". (Siddur Kol Haneshama, 1996:14)

- En otra versión del Sidur de la comunidad Kol Haneshamá de Jerusalén, Sidur "Avodá Shevalev", al rezo tradicional llamado "Psukei Dezimbrá" (cánticos selectos) que dice:

"Bendito sea Él, que con su verbo el mundo se hizo.
Bendito sea Él, creador del tiempo.

Bendito sea Él, que dice y hace.

Bendito sea Él, cuya misericordia extiende sobre la tierra.

Bendito sea Él, cuya misericordia extiende sobre sus criaturas.

Bendito sea Él, que recompensa a los que lo veneran.

Bendito sea Él, que existe hasta la eternidad.

Bendito sea Él, redentor y salvador, benito sea su nombre" (Sidur Seminario Rabínico Latinoamericano, 1999:10).

Lo modifican, alternando modos masculinos y femeninos de dirigirse a Dios:

"ברוך שאמר והיה העולם ברוך הוא. ברוך עושה בראשית ברוך אומר ועושה. ברוך גוזר ומקים. ברוכה

מרחמת על הארץ. ברוכה מרחמת על הבריות. ברוך משלם שכר טוב ליראיו. ברוכה גומלת חסד

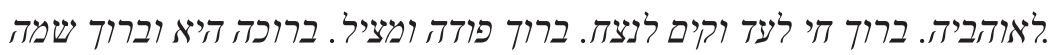

"Bendito sea Él, que con su verbo el mundo se hizo.

Bendito sea Él, creador del tiempo.

Bendito sea Él, que dice y hace.

Bendita sea Ella, cuya misericordia extiende sobre la tierra.

Bendita sea Ella, cuya misericordia extiende sobre sus criaturas.

Bendita sea Ella, que recompensa a los que lo veneran.

Bendito sea Él, que existe hasta la eternidad.

Bendito sea Él, redentor y salvador, bendita sea Ella, bendito su nombre". (Siddur, Avodah Shevalev, 1998: 28)

- En el último Sidur citado, cambian también una bendición, que en los libros de rezos tradicionales dicen:

"Bendito seas, oh Dios, que extiendes Tu manto de paz, sobre nosotros, sobre Tu pueblo Israel, y sobre Jerusalem" (Sidur Seminario Rabínico Latinoamericano, 1999:128)..
En el Sidur "Avodá Shevalev" dice:

שלום עלינו ועל כל עמה ישראל ועל ירושלים" "ברוכה את ה' הפורשת סוכת ירום"

"Bendita seas Tú (en la forma hebrea femenina de "Tü"), quien extiendes (conjugación del verbo en forma femenina) Tu manto de paz, sobre nosotros, sobre tu pueblo Israel, $u$ sobre Jerusalem". (Siddur, Avodah Shevalev, 1998: 28)

En todos estos ejemplos se pueden ver intentos de construir en el feligrés una imagen de la divinidad constituida por el género masculino y femenino, evitando que ésta sea vista de una única manera. La idea es que el feligrés pueda adoptar diferentes alternativas al dirigirse a Dios, teniendo en cuenta de que son diferentes maneras en que los humanos necesitamos volcar en el lenguaje para poder comunicarnos con Dios y expresar valores y concepciones acerca de la divinidad. 


\section{Dirigirse a dios de manera abstracta:}

Otra propuesta diferente al tema en que gira este artículo, es la de incluir imágenes abstractas de la divinidad con el fin de ser más fieles a cierta idea de Dios, acorde a la corriente más racionalista dentro de la tradición judía; siguiendo a Maimónides: "Que el Creador, bendito sea su nombre, es incorpóreo, no está sujeto a las leyes de la materia y que no tiene imagen ninguna" (Sidur, Seminario Rabínico Latinoamericano, 1999:358), y de esta manera, evitar asociarlo con imágenes del género humano, expresando que no es hombre ni mujer, Dios trasciende los límites corporales y materiales.

A continuación, algunos ejemplos de esta propuesta:

- Para la fórmula tradicional de decir bendiciones, en lugar de decir "Bendito eres Tú Adonai, Rey del universo...", se propone:

- "Bendito es nuestro Dios Eterno, Creador del universo...". (Siddur Gates of Prayer, 1975:51).

- "Bendito es el Único..." (Ídem., 53)

- "Bendita es la gracia...”. (Siddur Kol Haneshama Daily, 1996: 99).

- Bendito eres Tú Adonai, quien concede la vida al universo..." (חי העולעים). (Ídem., 15-17).

- En vez de la oración tradicional del "Barjü", que dice: "Bendecid a Adonai, pues él es digno de alabanza", se presenta: "ברכו את עין התיים", Bendecid a la fuente de la vida" (Falk, 1996:165).

- La bendición tradicional que se dice antes de comer el pan es: "Bendito eres Tú Adonai, Rey del Universo, quien extrae el pan de la tierra" y Marcia Falk lo escribe: "נברך את עין החיים המוציאה לחם מן האריץ",

"Bendigamos a la fuente de la vida, quien extrae el pan de la tierra" (Íbid., 19).

Se puede apreciar en estos ejemplos, la idea de acercarse a Dios con conceptos abstractos, que no remitan a cualidades masculinas o femeninas, sino que trasciendan esta división y se acerquen a una idea abstracta e indeterminada acerca de la divinidad, evitando antropormofirzarlo.

\section{Dirigirse a dios mediante cualidades femeninas estipuladas por la sociedad}

Esta tercera propuesta consiste en incluir en los rezos metáforas consideradas socialmente, para el mundo occidental, como femeninas como ser madre, cuidadora, maestra, piadosa, etc. Es interesante que muchas de estas metáforas femeninas acerca de la divinidad, se pueden encontrar en la misma Biblia Hebrea, no siendo metáforas populares ni usualmente utilizadas en la liturgia.

Algunos ejemplos extraídos de la Biblia Hebrea:

"Cual águila que despierta a su nido, sobre sus po-
lluelos aletea, despliega su plumaje y lo toma, lo
porta sobre su ala" [...] "lo amamantó con miel
de la peña y aceite del pedernal de roca" [...] "Al
Creador que te ha dado nacimiento, has olvidado.
Olvidaste a Dios, que te hizo nacer" (Deuterono-
mio 32:11, 13 y 18).

Aquí se describen cualidades claramente maternales, al percibir a Dios como un águila que protege a sus polluelos, los lleva consigo, los amamanta como lo hace una madre, y es quien los ha hecho nacer.

"Ciertamente, Dios ha dicho: ;Miren! Voy a extender sobre ella la paz y la riqueza de las naciones, como si fueran un río desbordado. Ustedes serán amamantados y llevados en brazos, y mimados en el regazo. Como uno a quien su madre le consuela, así yo os consolaré” (Isaías 66:12-13).

Nuevamente, la metáfora de Dios como madre, con el agregado que dice explícitamente que así como una madre consuela a sus hijos, así los hace Dios mismo.

"Escúchenme ustedes, los de la casa de Jacob, y todo el resto de la casa de Israel; ustedes, que han sido llevados desde que estaban en el vientre, sustentados desde que estaban en la matriz. Yo mismo los 
seguiré llevando, hasta que estén viejos y canosos. Yo los hice, yo los llevaré. Yo los apoyaré y los protegeré” (Isaías 46:3-4).

En estos versos se describe explícitamente una imagen en que Dios ha engendrado a sus hijos en su propio vientre, como le sucede a una madre, y que los sustenta, cuida y protege. Éstos son sólo algunos ejemplos, se pueden encontrar muchos más.

Algunas autoras, en esta dirección, han incorporado algunas plegarias especiales:

- YHVH nacimiento viviente

"YHVH nacimiento viviente

A orillas del Mar Rojo..."

“... YHVH partera,

con brazos fuertes y manos extendidas,

abriendo $\mathrm{Su}$ matriz,

Dando luz a la libertad" (Gottlieb, 1995: 17).

- Siguiendo la idea del rezo "Baruch She amar" (comprara con traducción tradicional en pag. 8):

"Bendita sea ella quien habló y el mundo se hizo. Bendita sea Ella.

Bendita sea Ella quien en el principio, dio a luz.

Bendita sea Ella quien dice y hace.

Bendita sea Ella quien declara y cumple.

Bendita sea Ella cuya matriz cubre la tierra.

Bendita sea Ela cuya matriz protege a todas las criaturas.

Bendita sea Ella quien alimenta a aquellos que tienen temor de Ella.

Bendita es Ella quien vive por siempre, y existe eternamente.

Bendita sea Ella quien redime y salva. Bendito sea Su nombre..." (Janowitz y Wenig, 1976: s.p.).

\section{Conclusiones}

A lo largo de este artículo se pudo plantear el problema teológico y social que presenta el hecho de dirigirse a Dios con cualidades, pronombres y sustantivos de género masculino, utilizadas en la liturgia judía. Se hizo un recorrido por diferentes propuestas para modificar, innovar e incorporar otras maneras de nombrar y acercarse a la divinidad.

Ahora llega el momento de pensar si es factible llevar a cabo estos cambios en la liturgia diaria de comunidades latinoamericanas. Sin duda, estos son cambios que provocan bastantes resistencias. Son años de rezar y nombrar a Dios de una manera determinada, son años de educar con estas metáforas de Dios, lo cual dificulta el cambio de imagen e incluso de género de la divinidad. Además, las sociedades latinoamericanas todavía están muy apegadas a valores y concepciones patriarcales.

Hay quienes critican estas propuestas diciendo que se haría una ruptura con los textos bíblicos, de donde provienen la mayoría de estas metáforas, por ejemplo:

"Unfortunately, advocates of what is identified as a feminist position introduce many changes that disrupt the integrity of Jewish liturgy which is so intimately connected to the language of the Hebrew Bible.” (Jules, 1997: s.p.) ${ }^{6}$

Bien podría responderse a estas críticas que podrían solamente utilizarse las mismas metáforas de género femenino o abstractas que figuran en la misma Biblia, como se vio en la tercera propuesta (ver págs. 14-16).

Otra posible crítica es que estas innovaciones en la manera de nombrar a Dios significarían una ruptura con la liturgia judía tradicional y sobre todo, provocaría cierto distanciamiento con corrientes religiosas judías fundamentalistas, quienes no aceptarían incluir estos cambios. En este sentido, sabemos que actualmente ya existen otros tipos de modificaciones en Sidurim de corrientes no ortodoxas y simplemente reflejan

6. "Desafortunadamente, los defensores de lo que se identifica como una posición feminista introducen muchos cambios que alteran la integridad de la liturgia judía, que está tan íntimamente conectada al lenguaje de la Biblia hebrea." (Jules, 1997: s.p.) 
visiones distintas acerca de la tradición judía. En los temas ideológicos, de alguna manera, ya estamos alejados, y no significa que estos cambios provoquen necesariamente un alejamiento mayor.

Ahora, si efectivamente se hicieran estas modificaciones, como se mencionó a lo largo del artículo, contribuiría a cambiar la imagen y mentalidad que tenemos acerca de la divinidad, más allá del género y otras cualidades humanas, e incluso ayudaría a valorar más el lugar de la mujer en la sociedad. Podría enriquecer nuestra espiritualidad, pudiéndonos acercar de una manera quizás aún más profunda.

Para finalizar, como lo afirma Neil Gillman:

"the process of creating new images of God never ends as long as there are people who continue to experience God's presence in their lives and to reflect on that experience" (Gillman, 2000: sp ) ${ }^{7}$.

En cada instante inefable, los seres humanos nos conectamos con la divinidad y esa experiencia trascendente nos posibilita el tener un determinado vínculo con Dios, especial y diferente a los demás. Mientras haya vínculo, las imágenes de Dios se multiplicarán. Lo importante es no estancarse en determinadas imágenes sino enriquecerse con la cercanía, amor y el significado de ese vínculo tan significativo para cada uno.

\section{Referencias}

Dorff Elliot N. (1993). Our Images of God in Knowing God: Jewish Journeys to the Unknowable, Jason Aronson Inc, USA.

Roth, Cecil (1971). Anthropomorphism en Encyclopedia Judaica vol. 3, Ed. Keter Publishing House, Israel: Jerusalem.

Falk Marcia (1999). Further Thoughts on Liturgy as an Expression of Theology in Contemporary Jewish Theology: A Reader, Eds: Elliot N. Dorff y Louis E. Newman, Oxford University Press, USA.

7. “el proceso de crear nuevas imágenes de Dios nunca termina, mientras haya personas que continúen experimentando la presencia de Dios en sus vidas y reflexionen sobre esa experiencia" (Gillman, 2000: sp).
Falk Marcia (1992). Introduction to New Blessings en Four Centuries of Jewish Women's Spirituality, Eds. Ellen M. Umansky y Dianne Ashton, Beacon Press USA:Boston.

Falk Marcia (1996). The Book of Blessings, Harper San Francisco, USA.

Falk Marcia (1999). Toward a Feminist Jewish Reconstruction of Monotheism en Contemporary Jewish Theology: A Reader, Eds. Elliot N. Dorff y Louis E. Newman, Oxford University Press, USA.

Gillman Neil (2000). The Way into Encountering God in Judaism, Jewish Lights, USA.

Gottlieb Lynn (1995). She Who Dwells Within: A Feminist Vision of a Renewed Judaism, Harper San Francisco, USA.

Gross Rita (1979). Female, God, Language in a Jewish context en Womanspirit Rising: A Feminist Reader in Religion, Eds. C. Christ y J. Plaskow, Harper San Francisco, USA.

Gross Rita (1983). Steps toward Feminine Imagery of Deity in Jewish Theology en On Being a Jewish Feminist: A Reader, Ed. Susannah Heschel, Nueva York, USA.

Harlow Jules (1997). Feminist Linguistics and Jewish Liturgy en Conservative Judaism Vol. 49/2, Ed. Rabbinical Assembly, USA: New York.

Yehuda Halevi, 1140, El Cuzari, traducción al español por Lázaro Schallman (1959). Editorial Sigal, Argentina: Buenos Aires.

Janowitz Naomi and Wenig Maggie (1976). Sidur Nashim: A Sabbath Prayer Book for Women, Editorial Providence, USA.

Majzor para Rosh Hashaná y Iom Kipur (1986). Editado por Consejo Mundual de Sinagogas y Seminario Rabínico Latinoamericano, Buenos Aires: Argentina.

Plaskow Judith (1976). The Jewish Feminist: Conflict In Identities en The Jewish Woman: New Perspectives, Ed. E. Koltun, Schocken Books, USA: New York.

Plaskow Judith (1983). The Right Question is Theologiacal en On Being a Jewish Feminist: A Reader, Ed. Susannah Heschel, USA: New York.

Plaskow Judith (1990). Standing Again At Sinai: Judaism From A Feminist Perspective, Harper San Francisco, USA.

Plaskow Judith (1994). Jewish Theology in Feminist Perspective en Feminist Perspectives on Jewish Studies, Eds. L. Davidman y S. Tenenbaum, Yale University Press: New Haven and London. 
Plaskow Judith (1997). Jewish Feminist Thought en History of Jewish Philosophy, Eds. Daniel H. Frank y Oliver Leaman, Routledge: London y New York.

Posada Kubissa, Luisa (1995). Pactos entre mujeres en Palabras clave sobre Mujer, Ed. Celia Amorós, cuarta edición. Editorial Verbo Divino, 2002, España.

Siddur Gates of Prayer, Central Conference of American Rabbis, 1975.

Siddur Kol Haneshama-Shabbat Eve, The Reconstructionist Press Wyncote, 1989 and 1996.
Siddur Sim Shalom, (Rabbi Jules Harlow) The Rabbinical Asembly The United Synagogue of America: New York, 1985 and 1998.

Siddur Kehilat Kol Haneshama, "Avodah Shevalev" (1998). Jerusalén, Israel.

Siddur Kol Haneshama /Daily (1996). Jerusalén, Israel.

Sidur editado por Consejo Mundual de Sinagogas y Seminario Rabínico Latinoamericano (1999). Buenos Aires: Argentina. 
- 